of Viesville, a query being appended to the genus on account of want of evidence as to dentition.

An inspection of the figures by which Prof. de Koninck's description is illustrated at once convinced me that not only was the query justifiable, but that the fish in question could not possibly belong to the genus Platysomus, the scales being represented as strongly denticulated on their hinder margins, besides being more obliquely arranged and differing essentially both in sculpture, and in the position of their articular spines, from those characteristic of the above-named genus.

I accordingly wrote to Prof. de Koninck, expressing these convictions, as well as my desire to see the specimens; whereupon my distinguished friend, with great kindness and courtesy, at once communicated my wish to the authorities of the Royal Museum of Natural History in Brussels, to whom I am much indebted for the opportunity of examining one of the specimens referred to.

As I had suspected, I find that it belongs to the genus Eurynotus, and to a species closely allied to, if not identical with, the wellknown Eurynotus crenatus, of the Scottish Lower Carboniferous rocks. This genus has hitherto been found only in Scotland (Agassiz's " Eurynotus" tenuiceps, from the American Triassic rocks, having turned out to be an Ischypterus), and the Viesville specimens are therefore the first veritable examples of Eurynotus which have been discovered elsewhere. In geological range, it remains, however, still confined to the Lower division of the Carboniferous formation, not a scale of Eurynotus having been as yet found above the horizon of the Millstone Grit.

R. H. Traquair.

Edinburgh, 14th April, 1879.

THE BRIDIINGTON AND SEWERBY GRAVELS.

SrR,-The gravels overlying the Purple Boulder-clay at Bridlington Quay have been generally considered as decidedly Post-glacial, if not quite recent.

I cannot now enter into a full discussion of the age of all these gravels; but a careful examination of the cliff has convinced me of the Glacial age of a portion of them. I made some sketches of the coast section last November, which I hope some day to publish; and these will, I think, convince any one of this; but at present I must confine myself to saying this much. On the north side of the town the Purple Boulder-clay is overlaid by gravels, which are shown to be of Glacial age by their contorted bedding, and by the way in which they are jammed into and against the Bonlder-clay. These crushed and crumpled gravels occur where the cliff is low, extending about as far as Sands Lane. North of this point the cliff rises at Potter Hill and continues to rise towards Sewerby; and along this part of the cliff the Boulder-clay is overlaid by gravels evenly bedded, which I call the Sewerby gravels. I shall not now discuss the question of the relation of these to the previously mentioned gravels. I will merely say that these Sewerby gravels, though as a rule evenly bedded, do exhibit in some places near their base contortions and 
crushings, such as bespeak ice-action, or inclose small masses of Boulder-clay in their lower layers; so that I consider it established, independently of further considerations, that these gravels at. all events date back to glacial times. I have other reasons for thinking so, but content myself at present with the above. I would only add that it by no means follows, because these gravels began to be deposited before ice-action had ceased in this area, that their deposition did not continue down to Post-glacial times. In other words, while their lower part is of Glacial, their upper part may be of Postglacial age.

South of the town is a corresponding cliff, consisting of current bedded sand and gravel, and finely laminated sandy clays (Phillips' Warp Beds). These do not show any undoubted signs of ice-action; they would seem, however, to have once been continuous with the Sewerby gravels, but to have had their continuity interrupted by the denudation of the valley by which the Gypsey Race escapes to sea.

In none of the above-mentioned beds have any shells been found as yet; this, though it proves nothing, is quite in keeping with the idea of their being of Glacial age, and is possibly due to their having been deposited in shallow seas freshened by the melting of the great ice-sheet; the current bedding, dipping now in one direction and now in the opposite, bespeaks tidal currents in shallow water, and the warp-like character of the laminated clays is equally suggestive of a tidal estuary.

I may mention that $I$ have found fragments of marine shells in sand-beds in the interior in localities where they have not been noticed before-viz. in the remarkable series of sand-hills running south from Harpham Moor and at Brigham. These, I suspect, will turn out to belong to the set of beds described by Phillips at pages 61 and 62 of his work on the Yorkshire Coast.

It is right to add that the gravels at Bridlington mentioned above are here and there overlaid or replaced by more recent fresh-water deposits, gravels, and marls. This, of course, is well known.

Bridulngton QuAT.

J. R. DAKYNS.

\section{GLACIAL TROUGHS BENEATH THE GLACIER DES BOSSONS.}

SIR,-Glacial grooves and furrows are always described in geological works as running in the direction of the ice-flow which formed them. That this should, perhaps generally, be the case, is so obvious that it may seem superfluous to give proofs thereof; nor are such far to seek; they are these : the direction of the grooves is often found to coincide with that of glacial striæ, with that of the transport of erratics, and with the direction of motion indicated by crag and tail, and by the forms of roches moutonnées. Yet it is not always so. In many cases grooves and furrows, such at least as are broad and shallow, must have been formed by ice moving not along but across the direction of the grooves. This would be apt to be the case especially on steep ground, and such I would call troughs. I saw a very good instance of this in the year 1873 , in the case of the Glacier des Bossons. From a point in the hill-side beyond the 